\title{
Periosteal Fibroma
}

National Cancer Institute

\section{Source}

National Cancer Institute. Periosteal Fibroma. NCI Thesaurus. Code C66761.

A benign fibrous neoplasm arising from the periosteal connective tissue that surrounds a bone. 